\title{
The Impact of Vertical R\&D Cooperation on Market Performance of Firms
}

\author{
Adam Karbowski, Jacek Prokop
}

\begin{abstract}
A B S T R A C T
Objective: The aim of this article is to investigate the impact of vertical R\&D cooperation on market performance of firms. Specifically, we explore the impact of vertical R\&D cooperation on firms' process innovation, outputs, market prices, and economic profits.

Research Design \& Methods: We apply microeconomic methods of analysis, i.e., mathematical modelling and optimisation procedures. We perform a comparative static analysis of two selected patterns of R\&D in a supply chain, i.e. independent behaviour of firms and behaviour of firms in a vertically integrated industry.
\end{abstract}

Findings: Vertical integration leads to significantly higher individual R\&D investments. For all values of knowledge spillovers, consumer surplus and social welfare are higher under vertical integration compared with the independent behaviour of firms. Under independent behaviour, profit of the supplier is significantly larger compared with the vertical integration. The profit of the final-good manufacturer is significantly lower under independent behaviour compared with the vertically integrated industry.

Implications \& Recommendations: In regard to business and public policy implications, the large knowledge spillovers promote consumer surplus and social welfare in the vertically integrated industry, while small knowledge spillovers promote process innovations in the vertically integrated industry.

Contribution \& Value Added: Firms' process innovation benefits from the vertical integration of the industry. Moreover, the greatest benefits from vertical integration for consumers and social welfare come from the largest knowledge spillovers in the industry.
Article type:
research article
Keywords:
vertical R\&D; supply chain; investments; process innovation; knowledge spillovers; social welfare

JEL codes:

\section{Suggested citation:}

Karbowski, A., \& Prokop, J. (2019). The Impact of Vertical R\&D Cooperation on Market Performance of Firms. Entrepreneurial Business and Economics Review, 7(4), 73-89. https://doi.org/10.15678/EBER.2019.070405 


\section{INTRODUCTION}

In the last 25 years, cooperation in research and development (R\&D) increased significantly due to important structural changes in the business environment of innovation-oriented enterprises (Van Beers \& Zand, 2014; Kosała, 2015; Wach, 2016; Dai, Zhang, \& Tang, 2017; Belderbos, Gilsing, Lokshin, Carree, \& Sastre, 2018; Capuano \& Grassi, 2019). First, the rising complexity of products and technologies dramatically increased the R\&D costs and risks for innovation-oriented firms, such that modern R\&D can hardly be dealt with by only relying on a firm's own investments, resources, or capabilities (van Beers \& Zand, 2014). As a result, networking or cooperating in R\&D with different and diverse partners - competitors, suppliers, buyers, universities, or research institutes - became a standard innovation activity, as witnessed by the rapid growth in strategic alliances with various R\&D partners in recent years (Hagedoorn, 2002; Belderbos, Carree, Diederen, Lokshin, \& Veugelers, 2004a; Wassmer, 2010; Van Beers \& Zand, 2014; Witek-Hajduk \& Napiórkowska, 2017; Belderbos et al., 2018; Karbowski \& Prokop, 2018; Bustinza, Gomes, VendrellHerrero, \& Baines, 2019). The globalisation wave of the last 25 years brought about significantly more possibilities for cross-national alliances and partnerships, which definitely contribute to competitive advantages of global firms in foreign markets (Lavie \& Miller, 2008; Van Beers \& Zand, 2014; Belderbos et al., 2018; Karbowski \& Prokop, 2018).

The business shift towards R\&D cooperation is reflected by the growing interest of scholars from diverse fields - e.g. economics, engineering, management, or sociology - in different forms of R\&D collaboration (see, e.g. Harryson, 2006; Belderbos et al., 2018). Surprisingly, there is a lot of research on horizontal R\&D cooperation (cooperation with competitors) and institutional R\&D cooperation (cooperation with universities or research institutes), but little on vertical R\&D cooperation (for overviews, see, e.g. Bhattacharya, d'Aspremont, Guriev, Sen, \& Tauman, 2012; Ge, Hu, \& Xia, 2014). The following paper aims to, at least to some extent, fill in the identified research gap by examining the impact of vertical R\&D cooperation on industry performance of firms. Specifically, our research questions consider the impacts of vertical R\&D cooperation on enterprise innovation, consumer surplus, and social welfare in the presence of knowledge spillovers in the industry. We contribute to the literature by showing when the benefits from the vertical R\&D cooperation are the highest for the firms' profits, innovation, consumer surplus, and social welfare. The relatively low values of knowledge spillovers the most effectively promote firms' innovation, while the relatively high values of knowledge spillovers the most effectively promote firms' profits, consumer surplus, and social welfare.

Using mathematical modelling and optimisation procedures, this article compares two models of vertical R\&D: (i) the independent behaviour of firms in a supply chain, and (ii) the behaviour of firms in a vertically integrated industry. In particular, we compare the values of R\&D investments, quantities (outputs), prices of the goods, economic profits, consumer surpluses, and the values of total welfare between industry setups under scrutiny.

The paper proceeds as follows. First, we review the relevant economics and management literature. Next, we briefly describe the materials and methods used in the present research. Then, we model R\&D activities of firms under two distinct industry setups: (i) the independent behaviour of enterprises in a supply chain, and (ii) the behaviour of firms 
under vertical integration. We discuss the obtained results in a section that follows and, lastly, draw conclusions in the final section of the article.

\section{LITERATURE REVIEW}

According to Un, Cuervo-Cazurra, and Asakawa (2008), knowledge obtained from cooperating with suppliers is quite narrow, since both suppliers and the cooperating firm operate in the same or similar industry. However, according to these authors, the knowledge provided by suppliers is still useful as a part of specialised set of skills possessed by suppliers and not the given firm. The cooperating firm can rely on its suppliers' specialised knowledge to create better products (Takeishi, 2002; Liu \& Atuahene-Gima, 2018).

Among many others, Hagedoorn (1993), Hendrikse (2003), Becker and Dietz (2004), Belderbos et al. (2004a; 2018), Belderbos, Carree, and Lokshin (2004b) and van Beers and Zand (2014) claim that firms may streamline and save R\&D and manufacturing costs within the supply chain by setting up the cooperative R\&D arrangements. Moreover, R\&D cooperation within the supply chain is often related to input or component improvements (Hagedoorn, 1993; Un et al., 2008; Capuano \& Grassi, 2019). R\&D cooperation with suppliers may also be beneficial for product innovations due to the existence of complementary product development capabilities between the cooperating firm and its suppliers (Un et al., 2008; Liu \& Atuahene-Gima, 2018). Furthermore, Clark (1989a; 1989b) observes that buyers can benefit from engaging suppliers in the product development through gaining better time-to-market of new products, reducing product development costs, or achieving product quality enhancements (Li \& Chen, 2018). Suppliers can also help the cooperating firm gain new competencies, share risks, or move faster into the new markets (Wynstra \& Weggemann, 2001; Un et al., 2008; Belderbos et al., 2018).

Most papers on the impact of R\&D cooperation on market performance of firms focus on the horizontal R\&D cooperation, i.e. R\&D cooperation between competitors. The seminal works by d'Aspremont and Jacquemin $(1988 ; 1990)$ compare the non-cooperative (R\&D competition) scenario to the cooperative one (R\&D cooperation or R\&D cartel). Scholars proved that total welfare is higher with cooperative R\&D (Bhattacharya et al., 2012) under sufficiently strong knowledge spillovers in the industry (for a wider discussion on the knowledge spillovers, see Marshall, 1890; Arrow, 1962; Jacobs, 1969; Romer, 1986; Porter, 1990; Glaeser, Kallal, Scheinkman, \& Shleifer 1992; Geroski, 1995). This result is confirmed by Kamien, Muller, and Zang (1992) in a more general model with the possibility of product differentiation. However, some suggest that the horizontal R\&D cooperation between firms may also lead to the anti-competitive behaviour of firms at the production stage (see, e.g. Belleflamme \& Peitz, 2010; Sovinsky \& Helland, 2012; Karbowski \& Prokop, 2018). As a result, the enterprises that cooperate in R\&D may collude on the final product market to the detriment of total welfare and consumer surplus (Leibowicz, 2018).

As Geroski (1992), Harabi (2002), and Ge et al. (2014) observe, vertical R\&D cooperation may perform better than the horizontal one, since the latter brings a significant risk of industry cartelisation. Moreover, vertical R\&D cooperation is a more frequent mode of cooperation between enterprises than the horizontal one (Arranz \& de Arroyabe, 2008; Ge et al., 2014; Dai et al., 2017). Surprisingly, little theoretical work appeared on vertical R\&D cooperation (cf. Inkmann, 2000; Ge et al., 2014). One of the notable exceptions is Steurs (1995), who extends the analytical framework developed by d'Aspremont and 
Jacquemin (1988) and shows that the vertical R\&D agreement is more likely to result in higher individual R\&D investments, output, and total welfare compared with the horizontal agreement (also see Ge et al., 2014). Allowing for both horizontal and vertical R\&D spillovers, Atallah (2002) investigates R\&D investments and total welfare among (i) noncooperative R\&D, (ii) two horizontal RJVs (research joint ventures), (iii) two vertical RJVs, and (iv) one complete RJV. The obtained results turned out ambiguous. In turn, following Kamien et al. (1992), Ishii (2004) analyses vertical R\&D cooperative arrangements (vertical R\&D cartels) with vertical non-cooperative RJVs and vertical RJV cartels (for interesting comparisons, see Manasakis, Petrakis, \& Zikos, 2014). The advantage of one of the above models of vertical R\&D over the others turned out to depend on the value of knowledge spillovers in the industry. Xu, Liang, Duan, and Xiao (2015) use the analytical framework developed by Kamien et al. (1992) to formally show that vertical R\&D cooperation is unstable, as the downstream firm is more likely to break the cooperation agreement. Therefore, when establishing R\&D cooperation, firms must carefully consider the reputation of potential partners and the extent of trust between the firms operating in the supply chain.

Manasakis et al. (2014) consider the downstream firms' incentives in a vertically related industry - to invest in cost-reducing R\&D (aimed at process innovations) and to form an RJV in the final product market - under two alternative modes of input (component) supply, i.e. (i) exclusive vertical relations and (ii) a single supplier. In contrast to the wellknown hold-up argument (for a brief elaboration, see e.g. Lemley \& Shapiro, 2007; Karbowski \& Prokop, 2015), in which downstream firms invest non-cooperatively and knowledge spillovers are relatively low, R\&D investments turn out to be higher under a single supplier mode than under competing vertical chains. Furthermore, downstream firms' incentives to create an RJV appear stronger in the former case than in the latter.

More recently, Dai et al. (2017) compare two cooperative R\&D behaviours in a supply chain, i.e. R\&D cartelisation and R\&D cost-sharing contract. The mathematical analyses led to conclusions that the upstream firm mostly favours an R\&D cartelisation behaviour, while the downstream firm prefers a non-cooperative scheme. For the upstream firm, it is always more profitable to cooperate with the downstream buyer than to operate under the vertical non-cooperative scheme. Under cooperation, the upstream supplier can effectively extract some surplus from the downstream buyer, to the detriment of the latter. Thus, the downstream firm favours a non-cooperative scheme. Supply chain-wide cooperation always benefits the consumers (in terms of consumer surplus) compared with a non-cooperative mode.

Belderbos et al. (2018) examine the collaboration in R\&D with the two value chain partners: customers and suppliers. The authors suggest that the firm's R\&D collaboration with either suppliers or customers constitutes the antecedent of the stable vertical integration of the industry.

Based on the above overview of the relevant literature, we formulate the following research hypotheses. First, drawing on Hagedoorn (1993), Steurs (1995), Hendrikse (2003), Becker and Dietz (2004), Ishii (2004), Belderbos et al. (2004a; 2004b; 2018), van Beers and Zand (2014), and Capuano and Grassi (2019), we hypothesise that vertical R\&D cooperation enhances firm's process R\&D investments and innovation. Second, drawing on Ishii (2004), Manasakis et al. (2014), and Capuano and Grassi (2019), we hypothesise that the innovation-related benefits from vertical $R \& D$ cooperation are the greatest for 
the relatively small knowledge spillovers in the industry. Third, based on Dai et al. (2017) and Belderbos et al. (2018), we hypothesise that the vertical R\&D cooperation benefits consumer surplus and social welfare compared with the vertical non-cooperative R\&D, especially for the larger knowledge spillovers in the industry.

The above hypotheses can be supported by the innovation economics and management theory. As Nieto and Quevedo (2005) notice, in the non-cooperative case, the knowledge spillovers constitute a significant disincentive to corporate investment in R\&D. This disincentive effect can be explained as follows. First, firms limit their investments in $R \& D$ if they perceive a smaller likelihood of being able to make exclusive use of the results of their R\&D works, i.e. knowledge spills over to other firms. Second, if they can use the stock of technological knowledge produced by other companies, imitators will do so to the detriment of their own investments in R\&D. The private R\&D investments should then decrease with the rising knowledge spillovers in the industry. The R\&D cooperation internalises knowledge externalities to some extent, and alleviates the disincentive effect mentioned above. As a result, the R\&D cooperation should enhance firms' R\&D investments and innovation. The smaller the knowledge spillovers, the smaller the disincentive effect and the larger R\&D investments and innovation. Therefore, the cooperative R\&D investments should dominate the non-cooperative ones, and the latter should be particularly visible for the relatively low values of spillovers in the industry.

Note that in the supply chains the inefficiency problem occurs, since the upstream firm faces incentives to raise the price of the intermediate good, and so charge a higher than efficient price of that good, to the detriment of the social welfare (Lemley \& Shapiro, 2007). The vertical cooperation solves the above inefficiency problem by mitigating the opportunistic behaviour of the upstream supplier. From the welfare perspective, knowledge spillovers can simultaneously play an important role in the economy, as the knowledge spillovers contribute to the diffusion of knowledge in the society and can work towards the promotion of the social welfare (Karbowski, 2016). Thus, taking into account both the inefficiency problem and the welfare promotion effect, we expect that the consumer surplus and total surplus benefit from vertical R\&D cooperation (the supply chain inefficiency is mitigated), and those benefits are the highest for the large spillovers in the industry (due to the welfare promotion effect).

\section{MATERIAL AND METHODS}

We apply standard microeconomic methods of analysis, i.e. mathematical modelling and optimisation procedures. As a complementary method, we further turn to the numerical analysis in order to show equilibrium solutions of the developed systems of equations. Data present in tables 1 and 2 are the numerical data which constitute the solutions of the systems of equations derived within the microeconomic models in the next section. All computations have been run in the Wolfram Mathematica 11 (2018) package. Using the above-mentioned tools, we perform a comparative static analysis of two selected patterns of R\&D behaviour of firms operating in a supply chain. For comparative purposes, and based on the literature review, we take into account the following variables: process R\&D investments (spendings on process R\&D), outputs (quantities produced by firms), market prices (market prices of the final goods), economic profits (total revenues net total costs), consumer surpluses (the monetary gain obtained by consumers), and total welfare values 
(the monetary gain of both consumers and producers). All these variables are measured directly (without the use of proxies) as the equilibrium values derived within the microeconomic model, and expressed in monetary (R\&D investments, market prices, economic profits, consumer surpluses, total welfare) or quantitative (outputs) terms.

\section{RESULTS AND DISCUSSION}

The following analysis considers two distinct cases, i.e. the independent behaviour of firms in a supply chain and the behaviour of firms in a vertically integrated industry.

\section{Independent R\&D activities}

We consider a supply chain with a final-good manufacturer, denoted as firm 1 and an input (component) supplier, denoted as firm 2. Firm 1 is assumed to face the market demand for its product given as a linear price function:

$$
p_{1}=a-q
$$

in which $p_{1}$ denotes the market price, $q$ is the volume produced by firm 1 , while $a$ is the demand intercept. After deciding about the level of production, firm 1 places an order to firm 2 for the input (component) used to produce final goods. Firm 2 supplies only the firm 1. It is assumed that the quantity of input equals the quantity of the final product. The price of the input set by firm 2 is denoted by $p_{2}$; if the component is under patent protection, the price of the input should also cover royalty rate. Initially, the cost functions of each firm are given by a quadratic function:

$$
\frac{q^{2}}{c}
$$

in which $c$ is a given parameter of an initial efficiency of a considered firm. The quadratic cost function allows for varying marginal costs of production which are closer to reality than the constant marginal cost of production resulting from the linear cost function (cf. Ahn \& McQuoid, 2017). Since the entry barriers to the industry are assumed to be high, there is no issue of new entry to this industry, both to the upstream and the downstream market. Thus, we consider a case of the bilateral monopoly in the supply chain.

Both firms decide about their levels of R\&D investments, $x_{i}$. The costs of investments are given as a quadratic function (such specification allows for diminishing marginal returns to R\&D that occur in business practice, compare e.g. Dasgupta, 1986):

$$
\gamma \cdot \frac{x_{i}^{2}}{2}
$$

in which $\gamma(\gamma>0)$ is a constant parameter. Since we focus on the impact of firms' R\&D investments and knowledge spillovers between companies on a firm's cost-reducing (process) innovation, we assume that the initial cost-related efficiencies (production cost efficiency and R\&D cost efficiency), $c$ and $\gamma$, are the same for both firms. In this way, we can concentrate on the relationship between the effective cost reduction of a single firm and firms' R\&D investments or knowledge spillovers between enterprises. The initial cost-related asymmetries between firms are excluded from the current study in order to isolate the links between $R \& D$ investments, knowledge spillovers, and process innovation.

When firm $i$ invests in R\&D, its cost of manufacturing is given by the following function: 


$$
C_{i}\left(q_{i}, x_{i}, x_{j}\right)=\frac{q^{2}}{c+x_{i}+\beta x_{j}}
$$

in which $x_{i}$ denotes the amount of R\&D investments made by the firm $i$, and $x_{j}$ denotes the number of R\&D investments made by the other firm. Parameter $\beta(0 \leq \beta \leq 1)$ determines the size of knowledge externalities, i.e. the benefits for a given company obtained as a result of research undertaken by the other firm. Higher levels of parameter $\beta$ mean that the $R \& D$ investments made by one enterprise allow the other firm to reduce the manufacturing costs by a greater amount for free. The parameter beta is the same for both companies.

For a given amount of R\&D investments, $x_{1}$ and $x_{2}$, the profit of firm 1 is given by:

$$
\pi_{1}=(a-q) \cdot q-\frac{q^{2}}{c+x_{1}+\beta x_{2}}-\gamma \cdot \frac{x_{1}^{2}}{2}-p_{2} q
$$

and the profit of firm 2 (component supplier) is written as:

$$
\pi_{2}=p_{2} q-\frac{q^{2}}{c+x_{2}+\beta x_{1}}-\gamma \cdot \frac{x_{2}^{2}}{2}
$$

The first order condition for profit maximisation of firm $1, \frac{\partial \pi_{1}}{\partial q}=0$, generates the optimal output level of the final good:

$$
q=\frac{\left(a-p_{2}\right)\left(c+x_{1}+\beta x_{2}\right)}{2\left(1+c+x_{1}+\beta x_{2}\right)}
$$

After substituting (7) into (6), the profit of firm 2 is given as:

$$
\pi_{2}=\frac{\left(a-p_{2}\right)^{2}\left(c+x_{1}+\beta x_{2}\right)^{2}}{4\left(c+\beta x_{1}+x_{2}\right)\left(1+c+x_{1}+\beta x_{2}\right)^{2}}+\frac{p_{2}\left(a-p_{2}\right)\left(c+x_{1}+\beta x_{2}\right)}{2\left(1+c+x_{1}+\beta x_{2}\right)}-\frac{1}{2} \gamma x_{2}^{2}
$$

The first order condition for profit maximisation of firm $2, \partial \pi_{2} / \partial p_{2}=0$, generates the optimal price level of the input as a function of R\&D investments of both firms; denoted by $p_{2}\left(x_{1}, x_{2}\right)$. By substituting $p_{2}\left(x_{1}, x_{2}\right)$ for $p_{2}$ into (5), (6) and (8), we obtain profits of both firms as a function of R\&D investments: $\pi_{i}\left(x_{1}, x_{2}\right)$.

Assuming that the firms decide about research spending independently and simultaneously, as the simultaneous strategic decisions taken by the supplier and the buyer are quite common in business practice (see, e.g. Dumrongsiri et al., 2008; Wu, Chen, \& Hsieh, 2012), we obtain the equilibrium levels of R\&D investments at the initial stage of the game by solving the following system of two equations with two unknowns, $x_{1}$ and $x_{2}$ :

$$
\frac{\partial \pi_{i}\left(x_{1}, x_{2}\right)}{\partial x_{i}}=0 \text { for } i=1,2
$$

Let us denote it by $\hat{x}_{1}$ and $\hat{x}_{2}$. Substituting $\hat{x}_{1}$ and $\hat{x}_{2}$ for $x_{1}$ and $x_{2}$ in (7), we obtain the equilibrium output of firm 1 (final-good manufacturer); denote it by $\hat{q}$. Now, we can also calculate the equilibrium levels of prices $\hat{p}_{i}$, profits $\hat{\pi}_{i}$, consumer surplus $\widehat{C S}$, and total welfare $\widehat{T W}$. Due to a relatively complex form of the analysed equations, a closed form solution to the system (9) cannot be obtained. For that reason, we turn to numerical analysis. A wide range of simulations for different levels of parameters $a, c$, and $y$ have been conducted. They showed that there was always a single solution to the system (9) in the set of nonnegative numbers and that the results of the model do not 
change. As an illustration of the results, we present the calculations for $a=100, c=1$, and $\gamma=3$. Table 1 shows the equilibrium for various levels of parameter $\beta$.

Table 1. Independent behaviour of firms in the supply chain: equilibrium outcomes for $a=100$, $c=1, \gamma=3$, and $\beta \in[0,1]$

\begin{tabular}{|c|c|c|c|c|c|c|c|c|c|}
\hline $\boldsymbol{\beta}$ & $\widehat{\boldsymbol{x}}_{\mathbf{1}}$ & $\widehat{\boldsymbol{x}}_{\mathbf{2}}$ & $\widehat{\boldsymbol{q}}$ & $\widehat{\boldsymbol{p}}_{\mathbf{1}}$ & $\widehat{\boldsymbol{p}}_{\mathbf{2}}$ & $\widehat{\boldsymbol{\pi}}_{\mathbf{1}}$ & $\widehat{\boldsymbol{\pi}}_{\mathbf{2}}$ & $\widehat{\boldsymbol{C S}}$ & $\widehat{\boldsymbol{T W}}$ \\
\hline $\mathbf{0 . 0}$ & 4.10890 & 4.36169 & 19.3950 & 80.6050 & 53.6173 & 424.47 & 941.21 & 188.08 & 1553.77 \\
\hline $\mathbf{0 . 1}$ & 4.05715 & 4.53818 & 19.7538 & 80.2462 & 53.3234 & 436.33 & 956.80 & 195.12 & 1588.24 \\
\hline $\mathbf{0 . 2}$ & 3.96530 & 4.71001 & 20.0615 & 79.9385 & 53.0849 & 447.01 & 969.80 & 201.23 & 1618.04 \\
\hline $\mathbf{0 . 3}$ & 3.84917 & 4.86908 & 20.3307 & 79.6693 & 52.8945 & 456.62 & 980.97 & 206.67 & 1644.26 \\
\hline $\mathbf{0 . 4}$ & 3.72434 & 5.00482 & 20.5696 & 79.4304 & 52.7446 & 465.21 & 990.91 & 211.55 & 1667.67 \\
\hline $\mathbf{0 . 5}$ & 3.60396 & 5.10972 & 20.7834 & 79.2166 & 52.6269 & 472.80 & 1000.00 & 215.97 & 1688.78 \\
\hline $\mathbf{0 . 6}$ & 3.49686 & 5.18157 & 20.9755 & 79.0245 & 52.5334 & 479.48 & 1008.50 & 219.99 & 1707.96 \\
\hline $\mathbf{0 . 7}$ & 3.40716 & 5.22269 & 21.1486 & 78.8514 & 52.4569 & 485.32 & 1016.52 & 223.63 & 1725.47 \\
\hline $\mathbf{0 . 8}$ & 3.33533 & 5.23793 & 21.3050 & 78.6950 & 52.3922 & 490.46 & 1024.10 & 226.95 & 1741.50 \\
\hline $\mathbf{0 . 9}$ & 3.27958 & 5.23287 & 21.4466 & 78.5534 & 52.3351 & 494.99 & 1031.26 & 229.98 & 1756.23 \\
\hline $\mathbf{1 . 0}$ & 3.23712 & 5.21272 & 21.5753 & 78.4247 & 52.2831 & 499.03 & 1038.01 & 232.75 & 1769.79 \\
\hline
\end{tabular}

Source: own study.

\section{Vertically integrated firms}

In this section, we move on to analyse the case of vertical integration of firms. Note that under vertical integration the duplication of the R\&D works - possible in the non-integrated industry - is avoided. The joint profit of integrated firms is given by:

$$
\pi=(a-q) q-\frac{q^{2}}{c+x_{1}+\beta x_{2}}-\gamma \frac{x_{1}^{2}}{2}-\frac{q^{2}}{c+x_{2}+\beta x_{1}}-\gamma \frac{x_{2}^{2}}{2}
$$

For a given amount of R\&D investments, $x_{1}$ and $x_{2}$, the first order condition for profit maximisation of integrated firms generates the following optimal output level of the final good:

$$
q=\frac{a}{2\left(1+\frac{1}{c+\beta x_{1}+x_{2}}+\frac{1}{c+x_{1}+\beta x_{2}}\right)}
$$

After substituting (11) into (10), the profit of integrated firms will become a function of R\&D investments, i.e., $\pi\left(x_{1}, x_{2}\right)$. The optimal level of research investments is obtained as a solution to the following system of two equations with two unknowns, $x_{1}$ and $x_{2}$ :

$$
\frac{\partial \pi\left(x_{1}, x_{2}\right)}{\partial x_{i}}=0 \text { for } i=1,2
$$

Let us denote the optimal level of R\&D investments as $x_{1}^{*}$ and $x_{2}^{*}$. By substituting $x_{1}^{*}$ and $x_{2}^{*}$ for $x_{1}$ and $x_{2}$ in $\pi\left(x_{1}, x_{2}\right)$, we next obtain the equilibrium profit of the vertically integrated firm; denote it by $\pi^{*}$. Now, we can also calculate the equilibrium level of output, $q^{*}$. Since the equilibrium is symmetric, we have $x_{1}^{*}=x_{2}^{*}$. We assume that the integrated firms split the profits equally, i.e., $\pi_{i}^{*}=0.5 \pi^{*}$, so the following results apply to that symmetric case. The symmetric division of profits in R\&D cooperation is a common case between firms with similar cost efficiencies (see, e.g. d'Aspremont \& Jacquemin, 1988; Kamien et al., 1992; Kamien \& Zang, 2000; Kaiser, 2002; Karbowski, 2016; Capuano \& Grassi, 2019). 
For the analysis of social efficiency, we also consider consumer surplus and total welfare. The consumer surplus, $C S^{*}$, is obtained as the area of a triangle under the demand curve and above the market price. The total welfare, $T W^{*}$, is calculated as the sum of consumer surplus and the profit of integrated firms.

Since a closed form solution to our model cannot be obtained, we use numerical analysis to find the equilibrium outcomes. Various levels of parameters $a, c$, and $\gamma$ have been applied to investigate the behaviour of firms. The basic conclusions seem to be invariant to the changes in these parameters.

We use the numerical analysis to find the equilibrium outcomes. For the purpose of this paper, we restrict our considerations to the case when three parameters of the model are: $a=100, c=1$, and $\gamma=3$; the same values as in the previous section, thus justified comparisons can be drawn in discussion. The equilibrium results of the numerical analysis, for various levels of parameter $\beta$, are given in table 2 .

Table 2. Vertical integration of firms in the supply chain: equilibrium outcomes for $a=100$, $c=1, \gamma=3$, and $\beta \in[0,1]$

\begin{tabular}{|l|l|l|l|l|l|l|}
\hline $\boldsymbol{\beta}$ & \multicolumn{1}{|c|}{$\boldsymbol{x}_{\boldsymbol{i}}^{*}$} & \multicolumn{1}{|c|}{$\boldsymbol{q}^{*}$} & \multicolumn{1}{c|}{$\boldsymbol{p}^{*}$} & \multicolumn{1}{c|}{$\boldsymbol{\pi}_{\boldsymbol{i}}^{*}$} & \multicolumn{1}{c|}{$\boldsymbol{C S}^{*}$} & $\boldsymbol{T W}^{*}$ \\
\hline $\mathbf{0 . 0}$ & 7.52406 & 40.4980 & 59.5020 & 927.53 & 820.04 & 2675.11 \\
\hline $\mathbf{0 . 1}$ & 7.39453 & 41.0185 & 58.9815 & 943.44 & 841.26 & 2728.15 \\
\hline $\mathbf{0 . 2}$ & 7.27211 & 41.4723 & 58.5277 & 957.48 & 859.98 & 2774.94 \\
\hline $\mathbf{0 . 3}$ & 7.15655 & 41.8722 & 58.1278 & 969.98 & 876.64 & 2816.61 \\
\hline $\mathbf{0 . 4}$ & 7.04744 & 42.2278 & 57.7722 & 981.20 & 891.60 & 2853.99 \\
\hline $\mathbf{0 . 5}$ & 6.94434 & 42.5465 & 57.4535 & 991.33 & 991.33 & 2887.76 \\
\hline $\mathbf{0 . 6}$ & 6.84679 & 42.8340 & 57.1660 & 1000.53 & 917.38 & 2918.44 \\
\hline $\mathbf{0 . 7}$ & 6.75437 & 43.0951 & 56.9049 & 1008.94 & 928.59 & 2946.48 \\
\hline $\mathbf{0 . 8}$ & 6.66667 & 43.3333 & 56.6667 & 1016.67 & 938.89 & 2972.22 \\
\hline $\mathbf{0 . 9}$ & 6.58331 & 43.5518 & 56.4482 & 1023.79 & 948.38 & 2995.95 \\
\hline $\mathbf{1 . 0}$ & 6.50397 & 43.7531 & 56.2469 & 1030.38 & 957.17 & 3017.92 \\
\hline
\end{tabular}

Source: own study.

Using table 1, we may discuss the impact of parameter beta, i.e. the extent of knowledge externalities (spillovers), on the equilibrium conduct and performance of firms in a supply chain. When the extent of knowledge spillovers increases, the downstream company (final-good manufacturer) reduces investments in R\&D. The R\&D spending of the upstream company (component supplier) simultaneously behaves non-monotonically with respect to beta. For the values of beta not greater than 0.8 , an increase in the level of technological spillovers encourages the upstream firm to invest more in R\&D. However, when beta exceeds 0.8 , research spending decline but are still significantly higher than the investments of the downstream company. The supply of the final product is an increasing function of beta, which translates into the declining price paid by consumers. The profits of both firms react monotonically to the size of externalities generated by the investments in R\&D. A wider extent of research spillovers in the industry results in higher profits for both companies. Thus, independently acting firms have incentives to engage in the exchange of research results to earn higher profits. Interestingly enough, the consumer surplus - but also the total welfare - are growing together with the size of research spillovers. 
Using table 2, let us now consider the impact of parameter beta, i.e. the size of knowledge externalities, on the equilibrium conduct of vertically integrated firms. When external benefits for a given company resulting from the research undertaken by the other firm are relatively small (parameter beta is low), R\&D investments of each firm are relatively high and decline with the growing scale of knowledge spillovers. The supply of the final product is also growing, which results in the declining level of the market price, and the highest consumer surplus. The profits of each firm and the total welfare are increasing together with the greater extent of technological spillovers.

Comparing tables 1 and 2, we may observe that vertical integration leads to significantly higher individual investments in R\&D for all values of knowledge spillovers in the industry. Moreover, for all values of knowledge spillovers, consumer surplus and total welfare are higher under vertical integration than the independent behaviour of firms. When we compare the economic profits, note that under independent behaviour of companies profit of the component supplier is significantly larger than under vertical integration. In turn, profit of the final-good manufacturer is significantly lower under independent behaviour of enterprises than in the vertically integrated industry. Interestingly, much more product is delivered in the marketplace - for all values of knowledge externalities - when the industry is vertically integrated than under independent behaviour of companies. The price of a final good is significantly higher when firms behave independently than under vertical integration.

Thus, from the social and policy viewpoint, it seems pretty straight-forward - that in our model - vertical integration serves enterprise innovation and social welfare better than the independent behaviour of firms in a supply chain. The latter is only beneficial to the upstream firm (component supplier), but it is mainly due to the equal split of profits under vertical integration. Slightly larger share of profits for the input supplier under vertical integration would make firm 2 prefer integration over independent behaviour.

Interestingly enough, the process innovation benefits from vertical integration are the highest for the lowest values of knowledge spillovers in the industry. By contrast, the greatest benefits from vertical integration for consumers and total welfare are for the largest knowledge spillovers in the industry. This may be an interesting observation for policy-makers who could be either oriented at industry innovation enhancement or social welfare improvement.

Clearly, the result that the greatest benefits from vertical integration for consumers and total welfare are for the largest knowledge spillovers in the industry is conditioned by the existing absorptive capacities of companies operating in the industry. Cohen and Levinthal (1989; 1990), Levin (1988), Levin, Klevorick, Nelson, and Winter (1987), Levin and Reiss (1988), and, recently, Jimenez-Barrionuevo, Molina, and Garcia-Morales (2019) indicate that enterprises differ in their ability to absorb knowledge produced by other firms. Thus, enterprises can be characterised by varying degrees, in which they can use knowledge spillovers occurring in the industry (see also Kaiser, 2002; Karbowski, 2016). The firm's absorptive capacity was first formalised by Kamien and Zang (2000). These authors consider a three-stage game in a Cournot duopoly. In the first stage of the game, firms made decisions about the level of generality of their research. The firm's absorptive capacity was defined as $\left(1-\delta_{i}\right) x_{i}^{\delta_{i}}$, in which $\delta_{i}$ stands for the degree of generality of research undertaken by $i$-th player, while $x_{i}$ denotes the firm's R\&D investments. Higher values of parameter delta 
correspond to a more specialised nature of research. For $\delta_{i}=1$ the $i$-th duopolist conducts very specialised research and the knowledge produced by the other firms is of no value to the given duopolist. Thus, when delta reaches its upper bound, the $i$-th duopolist does not absorb knowledge spillovers in the industry. By contrast, when $\delta_{i}=0$, the $i$-th firm conducts the very general research and the knowledge produced by others can be directly absorbed and utilised by the $i$-th enterprise. In the second stage of the game, the firms decide about the value of R\&D investments, and, in the next stage of the game, about the production volume of the final goods. Based on that model, Kamien and Zang (2000) show that an increase in the degree of generality of the firm's research leads to a higher enterprise R\&D investment, provided that the initial degree of generality of research is sufficiently high (for a more elaborate discussion, see Kamien \& Zang, 2000; Kaiser, 2002; Karbowski, 2016). Moreover, the authors show that R\&D cooperation between enterprises is more likely to occur, if prospective partners conduct more general research.

Based on the Kamien and Zang's (2000) observations, we suggest some appropriate implications for our model of behaviour in a supply chain. Based on Kamien and Zang (2000), we predict that the greatest benefits from vertical integration for consumers and total welfare are for the largest knowledge spillovers in the industry and the most general nature of research conducted by the enterprises operating in the industry. For very specialised research programmes undertaken by firms, the welfare benefits from vertical integration should be significantly smaller.

Another factor important in the discussion on the extent of R\&D spillovers in the industry is the organisation of R\&D activities on the given market. In their seminal paper, Kamien et al. (1992) distinguish four different forms of R\&D organisation that may arise between market rivals, i.e. (i) R\&D competition, (ii) R\&D (cooperation) cartelisation, (iii) RJV competition, and (iv) RJV cartelisation (see also Prokop, 2014; Karbowski \& Prokop, 2018; Capuano \& Grassi, 2019). In an R\&D competition, enterprises decide about their $R \& D$ investments unilaterally so as to maximise their individual profits. In an R\&D cartelisation, firms coordinate their R\&D investments but compete in the production of goods so as to maximise the sum of their profits. In an RJV competition, enterprises act as in the $R \& D$ competition, but they fully share results of R\&D (beta equal 1 ). In an RJV cartelisation, firms fully disclose their knowledge (beta equal 1 ) and coordinate their R\&D investments so as to maximise the sum of overall profits (for more details, please see Kamien et al., 1992). However, Kamien et al. (1992) do not take the vertical cooperation between firms into account. Please observe that - in our model of vertical relations - a wider extent of knowledge spillovers in the industry results in larger profits for both enterprises. Thus, independently acting firms have strong incentives to engage in the exchange of knowledge to achieve higher profits. Since the largest profits can be earned for maximal technological spillovers (beta equal 1), both firms face strong incentives to form an RJV. This will also work towards consumer surplus and total welfare maximisation.

Lastly, it seems interesting to discuss the behaviour of the input supplier. Observe that - in a non-integrated industry - the difference between the input price and the final product price is more than 26 monetary units. Under vertical integration, the final good price falls to about 60 monetary units at the maximum (being about 81 monetary units at the maximum prior to integration). Clearly, this decrease in the final product price is partly due to the elimination of the patent holdup problem by means of vertical 
integration. Prior to the integration, the upstream firm - as the patent holder - faces some incentives to raise the price of its component and so charge a higher than efficient patent royalty (Lemley \& Shapiro, 2007; Karbowski \& Prokop, 2015). Vertical integration eliminates those incentives of the patent holder.

\section{CONCLUSIONS}

In this article, we compared two models of corporate R\&D in a supply chain: the independent behaviour of firms and the behaviour of firms in a vertically integrated industry. With the use of microeconomic methods - i.e. mathematical modelling, optimisation procedures, and numerical analysis - we performed a comparative static analysis of two selected patterns of R\&D behaviour in a supply chain. Based on the obtained results, we can say that firms' process innovation benefits from the vertical integration of the industry. The innovation-related benefits are particularly high for the relatively small values of knowledge spillovers. In turn, the greatest benefits from vertical integration for consumers and social welfare are for the largest knowledge spillovers in the industry.

The analysis of firms' behaviour in a supply chain allowed us to conclude that, first, a wider extent of knowledge spillovers in the industry results in higher profits for both enterprises. Consequently, independently acting firms have incentives to engage in the exchange of research results in order to earn higher profits. This constitutes a direct implication for the managers who can boost firms' profits through the creation of the supply chain-wide RJV. Second, vertical integration leads to significantly higher individual investments in R\&D, higher market output (resulting in lower market price), larger consumer surplus, and total welfare (for all values of knowledge spillovers in the industry). From the public policy perspective, the vertical integration constitutes then a preferred option compared with the non-integrated industry. Third, the innovation-related benefits from vertical integration are the highest for the lowest values of knowledge spillovers, and the greatest benefits from vertical integration for consumers and social welfare are for the largest knowledge spillovers. It means that business managers focused on process innovation should not pursue an RJV option. On the other hand, managers oriented at short-term profits, can increase them thanks to the RJV creation. Fourth, the greatest benefits from vertical integration for consumers and social welfare should occur for the most general nature of research conducted by the enterprises operating in the industry. For very specialised research programmes undertaken by firms, welfare benefits from vertical integration should be significantly smaller. This is an interesting observation for policy-makers who can incentivise different natures of research undertaken by companies, i.e. more general (fundamental) or narrower (applied) research programmes. Fifth, vertical integration seems to eliminate incentives of the patent holder to raise the price of its component and charge a higher than efficient patent royalty. From the public policy perspective, it means that vertical integration of the supply chain solves the problem of patent holdup and subsequent royalty stacking, as this problem hinders innovation in the industry.

As regards possible future extensions of the present research, scholars may also consider the impacts of vertical R\&D cooperation on product innovation. However, the technical challenge is, then, how to model the impacts of product innovation? As a product quality enhancement parameter, as a market size expansion parameter, or in a totally different, original way? 
The lack of product innovation considerations constitutes a limitation of the current study. Another limitation is no consideration of the impact of competition either on the upstream or downstream market and the impact of competition on the equilibrium outcomes. However, the above limitations give rise to the new research endeavours and subsequent corresponding publications.

\section{REFERENCES}

Ahn, J., \& McQuoid, A. (2017). Capacity constrained exporters: Identifying increasing marginal cost. Economic Inquiry, 55, 1175-1191. https://doi.org/10.1111/ecin.12429

Arranz, N., \& de Arroyabe, J. (2008). The choice of partners in R\&D cooperation: an empirical analysis of Spanish firms. Technovation, 28, 88-100. https://doi.org/10.1016/j.technovation.2007.07.006

Arrow, K. (1962). Economic welfare and the allocation of resources for invention. In The Rate and Direction of Inventive Activity: Economic and Social Factors, pp. 609-626. Princeton, MA: UMI.

d'Aspremont, C., \& Jacquemin, A. (1988). Cooperative and Noncooperative R\&D in Duopolywith Spillovers. American Economic Review, 78, 1133-1137.

d'Aspremont, C., \& Jacquemin, A. (1990). Cooperative and Noncooperative R\&D in Duopoly with Spillovers: Erratum. American Economic Review, 80, 641-642.

Atallah, G. (2002). Vertical R\&D spillovers, cooperation, market structure, and innovation. Economics of Innovation and New Technology, 11, 179-209. https://doi.org/10.1080/10438590210903

Becker, W., \& Dietz, J. (2004). R\&D cooperation and innovation activities of firms evidence for the German manufacturing industry. Research Policy, 33, 209-223. https://doi.org/10.1016/j.respol.2003.07.003

Belderbos, R., Carree, M., Diederen, B., Lokshin, B., \& Veugelers, R. (2004a). Heterogeneity in R\&D cooperation strategies. International Journal of Industrial Organization, 22, 1237-1263. https://doi.org/10.1016/j.ijindorg.2004.08.001

Belderbos, R., Carree, M., \& Lokshin, B. (2004b). Cooperative R\&D and Firm Performance. Research Policy, 33, 1477-1492. https://doi.org/10.1016/j.respol.2004.07.003

Belderbos, R., Gilsing, V., Lokshin, B., Carree, M., \& Sastre, J. (2018). The antecedents of new R\&D collaborations with different partner types: On the dynamics of past R\&D collaboration and innovative performance. Long Range Planning, 51, 285-302. https://doi.org/10.1016/j.Irp.2017.10.002

Belleflamme, P., \& Peitz, M. (2010). Industrial Organization. Markets and Strategies. Cambridge: Cambridge University Press.

Bhattacharya, S., d'Aspremont, C., Guriev, S., Sen, D., \& Tauman, Y. (2012). Cooperation in R\&D: Patenting, Licensing and Contracting (CORE Discussion Paper 2012/55).

Bustinza, O., Gomes, E., Vendrell-Herrero, F., \& Baines, T. (2019). Product-service innovation and performance: the role of collaborative partnerships and R\&D intensity. R\&D Management, 49, 33-45. https://doi.org/10.1111/radm.12269

Capuano, C., \& Grassi, I. (2019). Spillovers, product innovation and R\&D cooperation: a theoretical model. Economics of Innovation and New Technology, 28, 197-216. https://doi.org/10.1080/10438599.2018.1461333

Clark, K. (1989a). Reducing the Time to Market: The Case of the World Auto Industry. Design Management Journal, 1, 49-57.

Clark, K. (1989b). Product Scope and Project Performance: The Effect of Parts Strategy and Supplier Involvement on Product Development. Management Science, 35, 1247-1263. 
Cohen, W., \& Levinthal, D. (1989). Innovation and learning: the two faces of R\&D. Economic Journal, 94, 569-596.

Cohen, W., \& Levinthal, D. (1990). Absorptive capacity: a new perspective on learning and innovation. Administrative Science Quarterly, 35, 128-152.

Dai, R., Zhang, J., \& Tang, W. (2017). Cartelization or Cost-sharing? Comparison of cooperation modes in a green supply chain. Journal of Cleaner Production, 156, 159-173. https://doi.org/10.1016/j.clepro.2017.04.011

Dasgupta, P. (1986). The Theory of Technological Competition. In J. Stiglitz \& F. Mathewson (Eds.), New Developments inthe Analysis of Market Structures. Cambridge: MIT Press.

Dumrongsiri, A., Fan, M., Jain, A., \& Moinzadeh, K. (2008). A supply chain model with direct and retail channels. European Journal of Operational Research, 187, 691-718. https://doi.org/10.1016/j.ejor.2006.05.044

Ge, Z., Hu, Q., \& Xia, Y. (2014). Firms' R\&D Cooperation Behavior in a Supply Chain. Production and Operations Management, 23, 599-609.

Geroski, P. (1992). Vertical relations between firms and industrial policy. Economic Journal, 102, 138-151.

Geroski, P. (1995). Do spillovers undermine the incentive to innovate?. In S. Dowrick (Ed.), Economic approaches to innovation. Aldershot: Edward Elgar.

Glaeser, E., Kallal, H., Scheinkman, J., \& Shleifer, A. (1992). Growth in Cities. Journal of Political Economy, 100, 1126-1152. https://doi.org/10.1086/261856

Hagedoorn, J. (1993). Understanding the Rationale of Strategic Technology Partnering: Interorganizational Modes of Cooperation and Sectoral Differences. Strategic Management Journal, 14, 371-385.

Hagedoorn, J. (2002). Inter-firm R\&D partnerships: An overview of major trends and patterns since 1960. Research Policy, 31, 477-92.

Harabi, N. (2002). The impact of vertical R\&D cooperation on firm innovation: An empirical investigation. Economics of Innovation and New Technology, 11, 93-108. https://doi.org/10.1080/10438590210900

Harryson, S. (2006). Know-who Based Entrepreneurship: From Knowledge Creation to Business Implementation. Cheltenham: Edward Elgar Publishing.

Hendrikse, G. (2003). Economics and Management of Organizations: Coordination, Motivation, and Strategy. New York: McGraw-Hill.

Inkmann, J. (2000). Horizontal and vertical R\&D cooperation. Center of Finance and Econometrics at the University of Konstanz (Discussion Paper 02/2000).

Ishii, A. (2004). Cooperative R\&D between vertically related firms with spillovers. International Journal of Industrial Organization, 22, 1213-35. https://doi.org/10.1016/j.ijindorg.2004.05.003

Jacobs, J. (1969). The Economy of Cities. New York: Random House.

Jimenez-Barrionuevo, M., Molina, L., \& Garcia-Morales, V. (2019). Combined Influence of Absorptive Capacity and Corporate Entrepreneurship on Performance. Sustainability, 11, 1-26. https://doi.org/10.3390/su11113034

Kaiser, U. (2002). An empirical test of models explaining research expenditures and research cooperation: evidence for the German service sector. International Journal of Industrial Organization, 20, 747-774. https://doi.org/10.1016/S0167-7187(01)00074-1

Kamien, M.I., Muller, E., \& Zang, I. (1992). Research Joint Ventures and R\&D Cartels. American Economic Review, 82, 1293-1306. 
Kamien, M., \& Zang, I. (2000). Meet me halfway: research joint ventures and absorptive capacity. International Journal of Industrial Organization, 18, 995-1012. https://doi.org/10.1016/S01677187(00)00054-0

Karbowski, A., \& Prokop, J. (2015). Patent hold-up and royalty stacking: the case of multipledownstream firms. Procedia-Economics and Finance, 24, 306-312.

Karbowski, A. (2016). The Elasticity-Based Approach to Enterprise Innovation. International Journal of Management and Economics, 49, 58-78. https://doi.org/10.1515/ijme-2016-0004

Karbowski, A., \& Prokop, J. (2018). R\&D activities of enterprises, product market leadership, and collusion. Proceedings of Rijeka Faculty of Economics: Journal of Economics and Business, 36, 735-753. https://doi.org/10.18045/zbefri.2018.2.735

Kosała, M. (2015). Innovation Processes as a Stimulant of Internationalisation Process of Firms. Entrepreneurial Business and Economics Review, 3, 65-84. https://doi.org/10.15678/EBER.2015.030206

Lavie, D., \& Miller, S. (2008). Alliance portfolio internationalization and firm performance. Organizational Science, 19, 623-46. https://doi.org/10.1287/orsc.1070.0341

Leibowicz, B. (2018). Welfare improvement windows for innovation policy. Research Policy, 47, 390398. https://doi.org/10.1016/j.respol.2017.12.009

Lemley, M, \& Shapiro, C. (2007). Patent Holdup and Royalty Stacking. Texas Law Review, 85, 19912049.

Levin, R., Klevorick, A., Nelson, R., \& Winter, S. (1987). Appropriating the returns from industrial research and development. Brookings Papers on Economic Activity, 3, 783-820.

Levin, R. (1988). Appropriability, R\&D spending, and technological performance. American Economic Review, 78, 424-428.

Levin, R., \& Reiss, P. (1988). Cost-reducing and demand-creating R\&D with spillovers. RAND Journal of Economics, 19, 538-556.

Li, W., \& Chen, J. (2018). Pricing and quality competition in a brand differentiated supply chain. International Journal of Production Economics, 202, 97-108. https://doi.org/10.1016/j.ijpe.2018.04.026

Liu, W., \& Atuahene-Gima, K. (2018). Enhancing product innovation performance in a dysfunctional competitive environment: The roles of competitive strategies and market-based assets. Industrial Marketing Management, 73, 7-20. https://doi.org/10.1016/j.indmarman.2018.01.006

Manasakis, C., Petrakis, E., \& Zikos, V. (2014). Downstream Research Joint Venture with Upstream Market Power. Southern Economic Journal, 80, 782-802. https://doi.org/10.4284/0038-40382012.110

Marshall, A. (1890). Principles of Economics. London: Macmillan.

Nieto, M., \& Quevedo, P. (2005). Absorptive capacity, technological opportunity, knowledge spillovers, and innovative effort. Technovation, 25, 1141-1157. https://doi.org/10.1016/j.technovation.2004.05.001

Porter, M. (1990). The Competitive Advantage of Nations. London: Macmillan.

Prokop, J. (2014). Research Joint Ventures and Cartelization of Industries. Procedia - Economics and Finance, 14, 507-514.

Romer, P. (1986). Increasing Returns and Long-run Growth. Journal of Political Economy, 94, 10021037. https://doi.org/10.1086/261420

Sovinsky, M., \& Helland, E. (2012). Do Research Joint Ventures Serve a Collusion Function?. Warwick Economic Research Papers No. 1030. 
Steurs, G. (1995). Inter-industry R\&D spillovers: What differences do they make?. International Journal of Industrial Organization, 13, 249-276. https://doi.org/10.1016/0167-7187(94)00455-B

Takeishi, A. (2002). Knowledge Partitioning in the Interfirm Division of Labor: The Case of Automotive Product Development. Organization Science, 13, 321-338. https://doi.org/10.1287/orsc.13.3.321.2779

Un, C., Cuervo-Cazurra, A., \& Asakawa, K. (2008). R\&D Collaborations and Product Innovation. SSRN Article 1139170.

Van Beers, C., \& Zand, F. (2014). R\&D Cooperation, Partner Diversity, and Innovation Performance: An Empirical Analysis. Journal of Product Innovation Management, 31, 292-312. https://doi.org/10.1111/jpim.12096

Wach, K. (2016). Innovative Behaviour of High-Tech Internationalized Firms: Survey Results from Poland. Entrepreneurial Business and Economics Review, 4, 153-165. http://dx.doi.org/10.15678/EBER.2016.040311

Wassmer, U. (2010). Alliance portfolios: A review and research agenda. Journal of Management, 36, 141-71. https://doi.org/10.1177/0149206308328484

Witek-Hajduk, M., \& Napiórkowska, A. (2017). A framework of retailer-manufacturer cooperation and coopetition: consumer durable goods retailers' case studies. Entrepreneurial Business and Economics Review, 5, 59-76. http://dx.doi.org/10.15678/EBER.2017.050104

Wolfram Mathematica. (2018). Version 11 [Home edition software for Windows].

Wu, C., Chen, C., \& Hsieh, C. (2012). Competitive pricing decisions in a two-echelon chain with horizontal and vertical competition. International Journal of Production Economics, 135, 265-274. https://doi.org/10.1016/j.ijpe.2011.07.020

Wynstra, F., \& Weggemann, M. (2001). Managing Supplier Involvement in Product Development: Three Critical Issues. European Management Journal, 19, 157-168. https://doi.org/10.1016/S0263-2373(00)00090-6

Xu, L., Liang, D., Duan, Z., \& Xiao, X. (2015). Stability Analysis of R\&D Cooperation in a Supply Chain. Mathematical Problems in Engineering, Article ID 409286. 


\section{Authors}

The contribution share of authors is equal and amounted to $50 \%$ each of them.

\section{Adam Karbowski}

Ph.D. in Economics (SGH Warsaw School of Economics), M.A. in Psychology (University of Warsaw). Assistant Professor in the Department of Business Economics, SGH Warsaw School of Economics. Scientific field: behavioural economics, experimental economics, industrial organisation. Adam Karbowski published his papers in 'Behavioural Processes', 'Economics and Sociology', 'Ekonomista', 'Journal of International Studies', 'Gospodarka Narodowa', and 'Personality and Individual Differences', among others.

Correspondence to: Adam Karbowski, PhD, SGH Warsaw School of Economics, Department of Business Economics, Al. Niepodległości 162, 02-554 Warsaw, Poland, e-mail: adam.karbowski@sgh.waw.pl

ORCID $\odot$ http://orcid.org/0000-0002-8725-1616

\section{Jacek Prokop}

Jacek Prokop, Ph.D. in Economics (Virginia Tech, USA), Professor, Vice Rector for International Relations, SGH Warsaw School of Economics. Head of the Department of Business Economics. Scientific field: computational economics, financial economics. Jacek Prokop published his papers in such journals as 'Economics Letters', 'International Journal of Industrial Organization', 'Journal of Development Economics', 'Journal of Economics', and 'Review of Financial Studies'.

Correspondence to: Prof. Jacek Prokop, PhD, SGH Warsaw School of Economics, Department of Business Economics, Al. Niepodległości 162, 02-554 Warsaw, Poland, e-mail: jacek.prokop@sgh.waw.pl

ORCID (1) http://orcid.org/0000-0001-5228-658X

\section{Acknowledgements and Financial Disclosure}

This research was supported by the National Science Centre, Poland (grant number UMO2017/25/B/HS4/01632).

\section{Copyright and License}

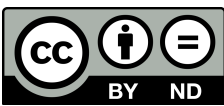

This article is published under the terms of the Creative Commons

Attribution - NoDerivs (CC BY-ND 4.0) License

http://creativecommons.org/licenses/by-nd/4.0/

\section{Published by the Centre for Strategic and International Entrepreneurship - Krakow, Poland}

The copyediting and proofreading of articles in English is financed in the framework 
